\title{
Clinico-Histopathological Studies in Canine Transmissible Venereal Tumour
}

\author{
Anup Yadav ${ }^{1}$, Praveen Kumar², Sandeep Panihar ${ }^{1}$, Umed Singh Mehra ${ }^{1}$, \\ N.S. Bugalia ${ }^{1}$, Rajendra Yadav ${ }^{3}$ and Pankaj Kumar ${ }^{4 *}$ \\ ${ }^{1}$ Department of Veterinary Gynaecology and Obstetrics (LUVAS, Hisar), Haryana, India \\ ${ }^{2}$ Department of Veterinary Medicine (LUVAS, Hisar), Haryana, India \\ ${ }^{3}$ RVDEC, Mahendergarh (LUVAS, Hisar), Haryana, India \\ ${ }^{4}$ Disease investigation laboratory, Rohtak (LUVAS, Hisar), Haryana, India
}

*Corresponding author

A B S T R A C T

\section{Keywords}

Dog, Clinical signs,

Transmissible venereal

tumour, Histopathology

Article Info

Accepted:

22 October 2018

Available Online:

10 November 2018
Present study included twenty-four dogs affected with Canine Transmissible Venereal Tumour (TVT). affected dogs were divided equally into three groups viz. vincristine therapy (Group I) with 7 day cycle and doxorubicin therapy consisting two groups i.e. Group II with 14 day cycle and group III with 21 day cycle and was aimed at diagnosing transmissible venereal tumour (TVT) initially using most common clinical signs and confirmation made by histopathological examination of biopsy tissue. Diagnosis based on clinical signs in all TVT affected dogs presented in teaching veterinary clinical complex (TVCC), Hisar revealed that continuous bloody discharge, excessive licking of genitalia, tumour growth were consistent in all affected dogs (100\%). Histopathology of affected dogs done before treatment revealed that tumour consisted of loose sheets of round polyhedral cells. These cells had large round top pleomorphic nucleus having prominent centrally placed nucleoli along with frequent mitotic figures and a few new blood vessels.

\section{Introduction}

Canine transmissible venereal tumour (TVT) is also called as sticker's tumor, venereal granuloma, canine condyloma, transmissible sarcoma, transmissible lymphosarcoma, histiosarcoma. TVT is a tumor of dog and other canids and it affects mainly the external genitalia. It is transmitted from animal to animal through exfoliation and transplantation of neoplastic cells occurring during sexual contacts, but can also be transmitted by dog bites, sniffs or licks of the tumour-affected areas (Cohen, 1985 and Johnston, 1991, Amaral et al., 2004). TVT usually affects the external genital organs, but presence of TVT lesion were reported in the skin, nasal mucosa, oral mucosa, eye, liver, lung, spleen, brain, uterus, ovary and mammary glands (Varughese et al., 2012; Milo and Snead, 2014; Komnenou et al., 2015; Rezaei et al., 2016). TVT appears as cauliflower like growth on external genitalia, multiple soft growths on the skin and show bleeding and sero-sanguineous discharge from prepucial orifice with tumour mass arising from base of 
penis in male while in the female, granulomatous tissue, haemorrhagic neoplastic nodules was observed in genital canal (Panchbhai et al., 1989, Ayyappan et al., 1994, Cristofori et al., 1985). The growths were pink, friable and bled even on slight manipulation (Ayyappan et al., 1994). Rogers et al., (1998) reported that the mean age of the dogs affected with TVT was 5 years (range 111 years).

Decreased chromosome number i.e. $57-64$ is found in tumour cells compared to normal chromosome number i.e. 78 in the TVT affected dogs (Rogers et al., 1997). Histopathology of neoplastic cells revealed round, ovoid and loosely arranged cells with large round top pleomorphic nucleus along with centrally placed prominent nucleoli with frequent occurrence of mitotic structures. The cells were separated by thin stroma but the cells were uniform in size. Plasma cells and macrophages along with lymphocytes were admixed with neoplastic cells along with focal areas of necrosis. A typical alveolar arrangement of the tumor cells limited by moderately defined fibrocollagenous strands with mitotic figures. The uniform architectural pattern of tumor cells was suggestive of venereal granuloma (Das et al., 1990, Lal Krishna and Gupta, 1990, Chang et al., 1999, Rodrigues et al., 2001). Diagnosis of TVT is most commonly done by clinical examination and confirmation is made by histopathological examination of biopsy tissue (Moulton, 1978; Richardson, 1981; Daleck et al., 1987).

\section{Materials and Methods}

Twenty four dogs (male and female) with the history of bleeding from penis, prepuce and cauliflower like tumorous growth on base of penis in males and females having history of vaginal bleeding and cauliflower like growth in vagina following mating were examined by backward retraction of prepuce in male dogs and per vaginum in female dogs and confirmed by the presence of cauliflower like tumour mass on the base of penis and vagina. The tumors were examined for shape, size, location and presence of bleeding associated with them. Histopathological studies of biopsy tissues of tumour were done by fixing tumour biopsy tissue in $10 \%$ neutral buffered formalin for 24 hours and then embedded in paraffin wax, sectioned and subsequently five $\mu \mathrm{m}$ thick sections were stained with hematoxylin and eosin (H \& E) stain (Carleton and Leach, 1947). Slide of histopathology examined under light microscope (Sales Lapa et al., 2012).. Biopsy tissues for histopathology examination were obtained before treatment with chemotherapeutic drugs.

\section{Results and Discussion}

In present study, Cauliflower like tumour growth on external genitalia, bloody discharge and excessive licking of genitalia were the most common clinical signs observed in all the dogs affected with TVT. These observations were also recorded by many other clinicians (Panchbhai et al., 1989). Recorded lower incidence of clinical symptoms viz. Anorexia, vulvuar edema and dehydration is due to late reporting of affected dogs from rural areas as these clinical signs are much common during early phase of the disease (Gandotra et al., 1993). Pyrexia observed in TVT affected dogs is associated with secondary bacterial infection of tumour mass consequential upon coital injury (Batatatnuzi and Kristensen, 2008).

Histopathology of tumour biopsy tissue obtained before chemotherapy evidenced loose sheets of round, ovoid and loosely arranged polyhedral cells and tumour cells have large round top pleomorphic nucleus, having prominent centrally placed nucleoli along with frequent mitotic figures and a few new blood vessels (Fig. 1). 
Chart.1 Histogram showing clinical symptoms in TVT affected male and female dog

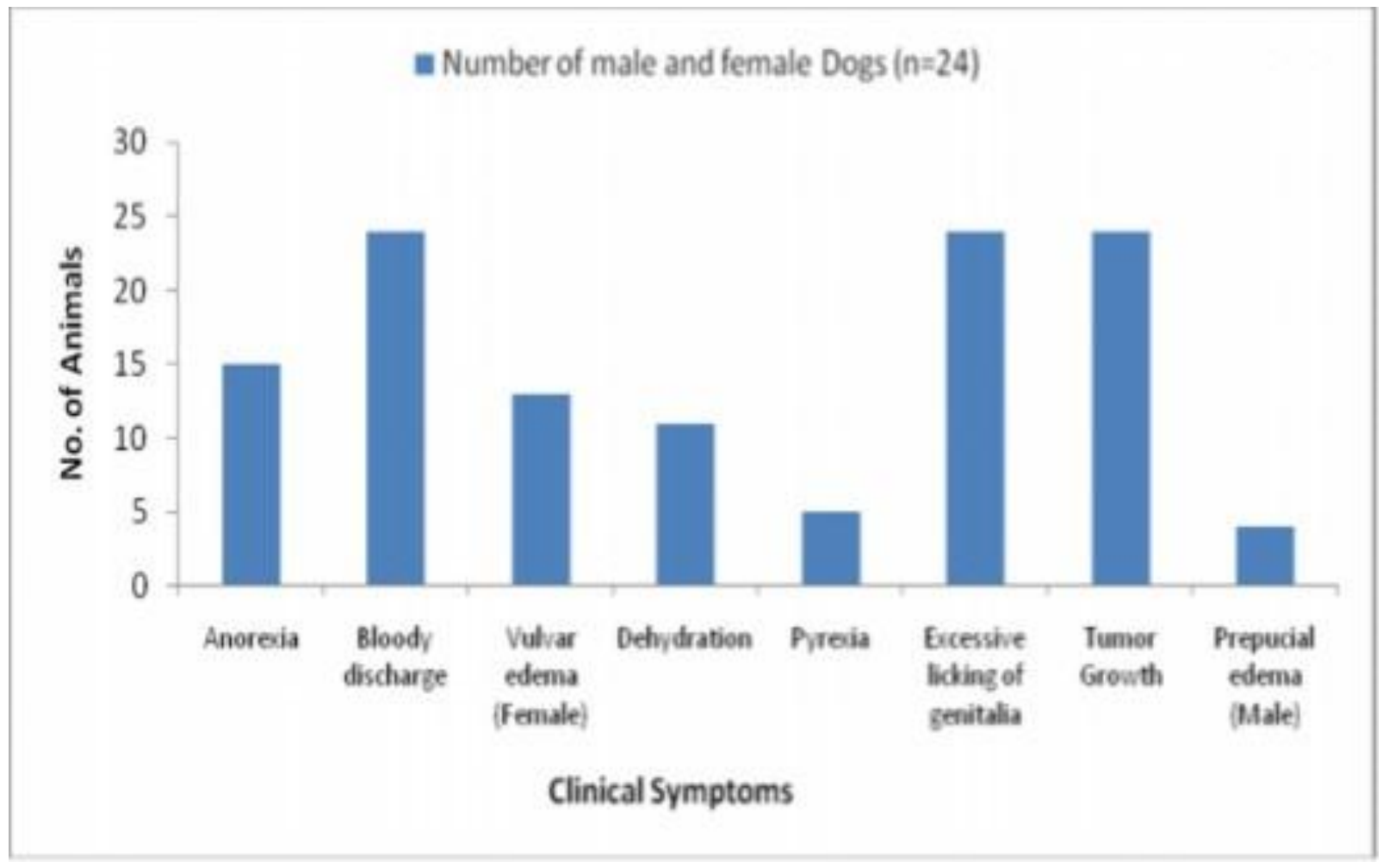

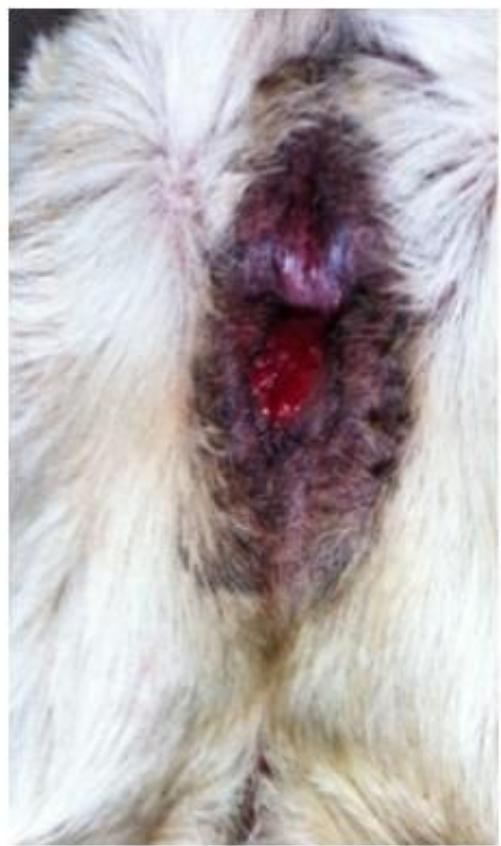

Vaginal bleeding in TVT

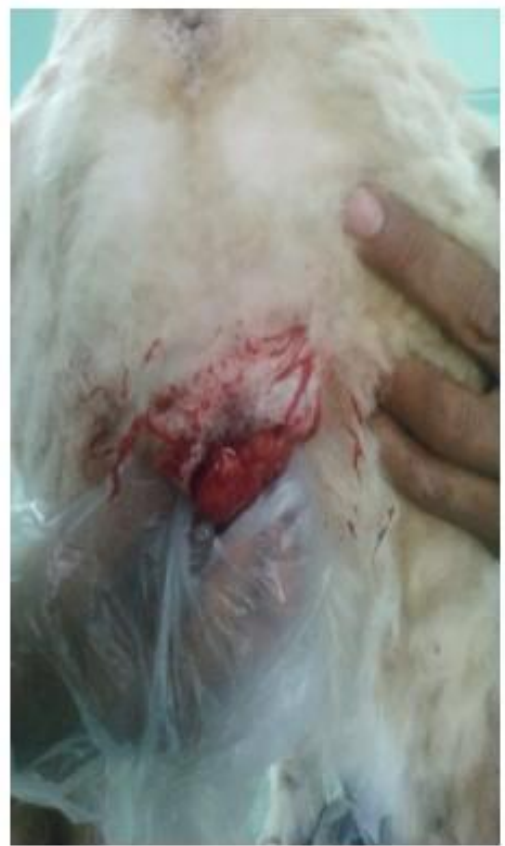

Cauliflower shaped growth of tumour protruding outside in TVT affected female dog 
Fig.1 Micro Photograph of TVT tissue showing tumour cells with prominent nuclei and large vacuoles (H\&E stain; Magnification 40x)

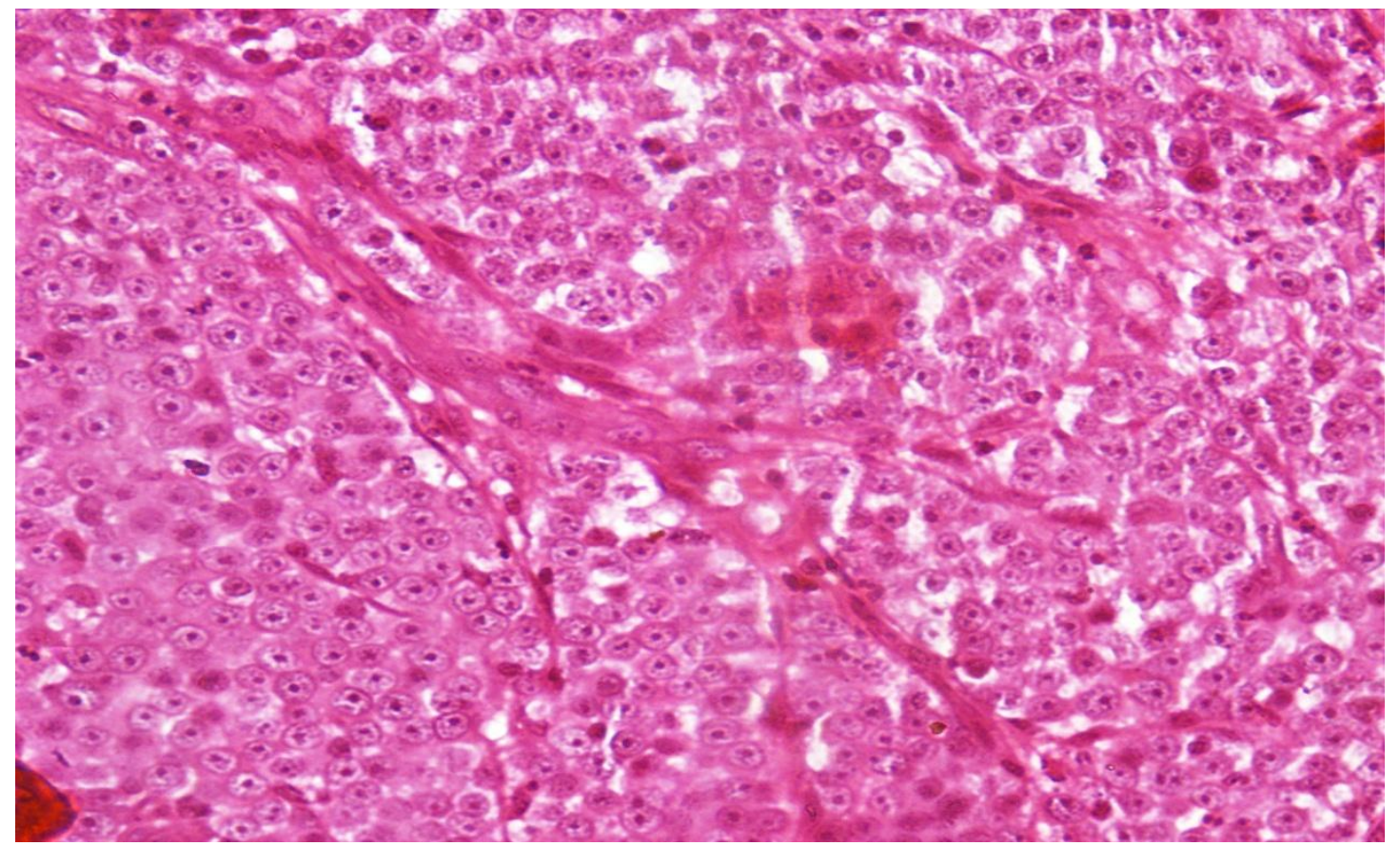

The histopathological examination which confirmed the diagnosis of TVT, was congruous with a previous study which demonstrated the tumor as confluent sheet or rows of tumor cells separated by little fibrous stroma (Ayyappan et al., 1994). Tumor cells were infiltrated by macrophages, lymphocytes, and plasma cells with schirrous reaction characterized by intense fibroblastic proliferation and collagen deposition (Das et al., 1990, Lal Krishna and Gupta, 1990, Chang et al., 1999, Rodrigues et al., 2001, Nak et al., 2005).

The presence of large numbers of lymphocytes, plasma cells and activated macrophages in the tumor strongly suggests a role for localized antibody-mediated control of TVT (Mascarenhas et al., 2014). Similar histopathological observations were also recorded in canine TVT in earlier reports (Panchbhai et al., 1990 and Chang and Chihhuan, 1997). Appearance of new blood vessels is suggestive of increased blood supply to meet nutrient and oxygen requirement of increased mitotic activity of tumour cells (Lal Krishna and Gupta, 1990).

The present findings are suggestive that Cauliflower like tumour growth on external genitalia, bloody discharge and excessive licking of genitalia were the most common clinical signs observed in TVT affected dogs. Histopathology of TVT affected dogs showed neoplastic tumour cells having large round top pleomorphic nucleus having prominent centrally placed nucleoli along with frequent mitotic figures which is most confirmatory diagnosis in canine TVT.

\section{References}

Amaral, A.S., Gaspar, L.F.J., Bassani-Silva, S., Rocha, N.S. (2004). Cytological diagnostic of transmissible venereal tumor in the Botucatu region, Brazil (descriptive study: 1994-2003). Rev. Port. Cienc. Vet. 99: 167-171. 
Ayyappan, S., Sureshkumar, R., Ganesh, T. N. and Archibald David, W. P. (1994). Metastatic venereal tumour in a dog, a case report. Ind. Vet. J. 71(3):265-266.

Batatanuzi, E. K. and Kristensen, F. (2008). Urinary tract infection: The role of canine transmissible venereal tumor. $J$ Small Anim. Pract. 37: 276-279.

Carleton, H.M. and Leach, E.M. (1947). Histological technique $2^{\text {nd }}$ Ed. London; Oxford University Press.

Chang, S. C., Huan, Y.C., Chang, S.C. and Yang, C.H. (1999). Cytological and histological features of cutaneous round cell tumors in dogs. $J$. of the Chinesesoc. of vety sci.25(2): 139-152.

Chang, S. C., and Chihhuan, Y. (1997). Cytology of venereal tumours in dogs. Vet. Bull. 67: 959.

Cohen D. (1985). The canine transmissible venereal tumor: A unique result of tumor progression. Adv Cancer Res.43:75-112.

Cristofori, F., Aaden A.S and Gheddi A. M (1985). Description of a transmissible venereal tumour in a dog in Somalia, Description du sarcomevenerien transmissible chez un chien (sarcoma de Sticker) en Somalie Revue de, Elevageet-de-Medecine-Veterinaire-des-PaysTropicaux. 38(3): 235- 238.

Daleck, C. L. M., Daleck, C. R., Ferreira, H., and Santana, A.E. (1987). New studies on treatment of canine transmisstble venereal tumour (TVT). Ars. Veterinaria, 3: 203-209.

Das, A. K.., Das, U., Das, D., and Sengupta, J. (1990). Histopathological study of canine transmissible venereal tumour. lnd.Vet.J., 67 (5): 473-474.

Gandotra, V.K., Chauhan, F.S., and Sharma, R.D. (1993). Occurrence of canine transmissible venereal tumour and evaluation of two treatments. Indian Veterinary Journal, 70: 854-857.
Johnston, S.D. (1991). Performing a complete canine semen evaluation in a small animal hospital. Vet Clin North Am Small AnPract. 21(3):545-551.

Komnenou, A.T., Thomas A.L and Kyriazis, A. P. (2015). Ocular manifestations of canine transmissible venereal tumour: a retrospective study of 25 cases in Greece. Vet Rec. 176:523.

Lalkrishan, and Gupta, V.K. (1990). Neoplasm in dog in Himachal Pradesh. Ind. Vet. J. 14:278-281.

Mascarenhas, M.B., Peixoto, P.V, Ramadinha, R.R. (2014). Immunohistochemical study of genital and extragenital forms of canine transmissible venereal tumor in Brazil. Pesq Vet Bras.34:250-254.

Milo, J and Snead, E. (2014). A case of ocular canine transmissible venereal tumor.Can Vet J, 55:1245.

Moulton, J.E. (1978). Tumor of genital systems. In: Moulton JE, ed. Tumors in domestic animals. 2.ed. California: University of California; 326-330.

Nak, D., Nak, Y and Cangul, I.T. (2005). A Clinico-pathological study on the effect of vincristine on transmissible venereal tumour in dogs. Journal of veterinary medicine. 52: 366-370.

Panchbhai, V.S., Karpe, A.G., Kulkarni, G.B., and Kulkarni, S.K. (1990). Use of autogenous vaccine in transmissible canine venereal tumour. Indian Veterinary Journal, 67:983-984.

Panchbhai, V.S., Kulkarni, G.B.., Bakshi, S.A., and Pargaonkar, D.R. (1989). A Clinical case of venereal tumour associated with fibroma of cervix in a bitch. Livestock Adv 14(8) 40-41.

Rezaei, M., Azizi, S and Shahheidaripour, S. (2016).Primary oral and nasal transmissible venereal tumor in a mixbreed dog. Asian Pacific $J$ Trop Biomed, 6:443-445. 
Richardson, R.C. (1981). Canine Sales- Lapa, F. A., Andrade, S.F. and transmissible venereal tumour. Comp Contin Educ Pract Vet; 3:951-956.

Rodrigues, G.N., Alessi, A. C. and Laus, J. L. (2001). Intraocular transmissible venereal tumor in a dog. Ciencia-Rural. 31 (1):141-143.

Rogers, K. S., Walker, M.A. and Dillon, H.B. (1998).Transmissible venereal tumour a retrospective study of 29 cases. J. Am. Anim. Hospital Asso., 34: 338-339.

Rogers, K.S. (1997). Transmissible venereal tumor. Comp Contin Educ Pract Vet., 19: 1036-1045.

Gervazoni,

Histopathological and cytological analysis of transmissible venereal tumor in dogs after two treatment protocols. In: Colloquium Agrariae, pp: 36-45.

Varughese, E., Singla, V. and Ratnakaran, U., (2012). Successful management of metastatic transmissible venereal tumour to skin of mammary region. Reprod Domest Anim, 47:366-369.

\section{How to cite this article:}

Anup Yadav, Praveen Kumar, Sandeep Panihar, Umed Singh Mehra, N.S. Bugalia, Rajendra Yadav and Pankaj Kumar. 2018. Clinico-Histopathological Studies in Canine Transmissible Venereal Tumour. Int.J.Curr.Microbiol.App.Sci. 7(11): 2714-2719.

doi: https://doi.org/10.20546/ijcmas.2018.711.310 